\title{
The Impact of Foreign Direct Investment (FDI) on Economic Growth in Eastern Africa: Evidence from Panel Data Analysis
}

\author{
Seiko Minota Zekarias ${ }^{1}$ \\ ${ }^{1}$ Department of Development Economics, Ethiopian Civil Service University, Addis Ababa, Ethiopia. \\ Correspondence: Seiko Minota Zekarias, Department of Development Economics, Ethiopian Civil Service University, \\ Addis Ababa, Ethiopia. E-mail:zms.ethiopia@gmail.com
}

Received: December 4, 2015

Accepted: December 16, 2015

doi:10.11114/aef.v3i1.1317

URL: http://dx.doi.org/10.11114/aef.v3i1.1317

\begin{abstract}
This study has analyzed the impact of Foreign Direct Investment (FDI) on Economic growth in 14 Eastern Africa countries by employing 34 years (1980-2013) panel data, using dynamic GMM estimators after checking for autocorrelation and model specification tests. Developing countries have been attracting FDI attempting to reduce resource gaps, technology gap, unemployment and trade deficits. However, unlike classical growth theories, the empirical studies sought inconclusive effect of FDI on growth. The findings confirm that FDI has positive and marginally significant effect of FDI on economic growth, the rate of economic conditional convergence at $5 \%$, absence of significant crowding out effect moving from FDI to domestic investment, interdependence of domestic investment and trade openness in the sub-region. Thus, I conclude that FDI is a key deriver of economic growth and a catalyst to economic conditional convergence in Eastern Africa; so, the subregion need to attract more FDI by improving investment environment, strengthening regional integration, developing human capital and basic infrastructure, and promoting export-oriented investment.
\end{abstract}

Keywords: Foreign Direct Investment (FDI), Economic Growth, Eastern Africa, Generalized Method of Moments (GMM)

\section{Introduction}

\subsection{Background}

International Institute for Sustainable Development [IISD] (Mann et.al., 2005), acknowledged the role Foreign Direct Investment (FDI) for sustainable development. Globalization and resource gap has enhanced the global flow of FDI especially since 1980s (UNCTAD, 2014). For instance, the world inflow of FDI rose from \$13.3billion in 1970 to $\$ 1.45$ trillion in 2013; while the developing countries share went from $\$ 3.8$ billion to $\$ 0.8$ trillion in the same period. Similarly, the inflow of FDI to Africa increased from \$1.3 billion in 1970 to $\$ 57.2$ billion and that of Eastern Africa went from $\$ 0.1$ billion to $\$ 14.6$ billion. Although the abosolute inflow figure has increased overtime at world level, the developed countries have ever received larger share of FDI than the developing ones except in 2012 and 2013.

The question of development in Africa and Eastern Africa (EA) remains a series challenge. The region never met investment demand mainly due to capital constraint. Economic growth is determined by the level of investment and saving, the sub-region's saving is quite low (Joupouognigni and Ndambendia, 2010; Alfaro, et.al, 2003). On the otherhand, the ever increasing population demands more than what the sub-region can supply as its productive capacity is very low (Kabundi \& Loots, 2012; Kinyondo, 2012, Adb,2013 ). To address such problems, many developing countries including Africa took investment reforms to attract more foreign investment. Consequently, more than half of all private capital flows to developing countries was accounted by FDI in 1988 (UNCTAD, 1999,2008,2012). Similarly, the growth rate of FDI inflows to Africa and Eastern Africa has increased in absolute terms between 1970 and 2013 (Esso, 2010; UNCTAD, 2014). Eastern Africa has been attracting large number of foreign investors. For example, while Africa's FDI share out of developing countries fall from 33\% in 1970 to $7.3 \%$ in 2013, EA share out of Africa rose from $6.3 \%$ in 1970 to $25.5 \%$ in 2013. Despite the rise in FDI inflows to EA, its impact did not studied well by applying dynamic growth methods.

African Development Bank [AfDB] (2014) stated thirteen (13) Eastern Africa countries; including five landlocked nations: Burundi, Rwanda, Uganda, South Sudan and Ethiopia; two island nations: Comoros and Seychelles; and six coastal countries: Somalia, Sudan, Eritrea, Djibouti, Kenya and Tanzania. The existence of growing population, expanding market, untapped natural resources with diverse culture, history and social value can give EA competitive 
strength. During the last decade, EA has been among the fastest growing regions in the world. It could achieve an average real GDP growth of $6.6 \%$ per annum (2000-2009) which approaches the millennium development target of $7 \%$ per annum; how to sustain high growth rates and make growth more inclusive become the current challenge (AfDB,2014). Despite remarkable improvements in access to social services (e.g. education and health), yet substantial variability is observed in the sub-region.

Given huge development potential, EA is still among the poorest regions. Food insecurity, malnutrition and gender inequality; continuous conflict remains substantial bottleneck of the sub-region. The three basic economic sectors; agriculture, industry and service are less productive. Agriculture- the dominant sector follows traditional system, which do not produce surplus. The industry remains infant while the service sector recently accounts larger share of GDP, implying the presence of poor forward and backward linkages among the sectors (AfDB, 2014). African competitiveness report 2015 underlined the importance of structural transformation to ensure sustainable development in the countries of sub-region (World Economic Forum [WEF], 2015).

\subsection{The Problem and Purpose}

Although most gorwh theories aknowledge the direct and indirect contribution of FDI to investment and growth (Rugman ,2010), the empirical evidences indicate that the development role of FDI is controvesial (Agrawal, 2011; Alege \& Ogundipe, 2013). The proponents of FDI argue that FDI is an alternative source of capital, technology and skill gain, increase production and trade networks; enhance socioeconomic development (OECD, 2002, 2008). Contrary to this, some other shcholars (Abadi, 2011; Agrawal, 2011; and Abdulahi, 2012; Alege \& Ogundipe, 2013) argue that FDI retards economic growth through crowding out of domestic infant industries, exploiting local resources, repatriating profits to their home countries, opening door for corruption by some public officials. Also both host and home country, industry specific factors can condition the growth impact of FDI (Eddine, et. al., 2014).

Past emprical studies contradiction might be due to methodological problems of using linear models for such dynamic growth model and exclusion of some important explanatory variables. Linear models can not capture unobserved counry specific influences, which may yield baised and inconsstent results. To address this, the dynamic GMM was used, which systematically captures both random and fixed effects. Analyzing the actual effect of FDI is vital to provide concrete information for policy makers,governmwents and development actors. Therefore,the purpose of the study was to investigate the impact of FDI on economic growth and to examine the economic conditional convergence in Eastern Africa.The analysis was based on endogenous growth theory especially on eclectic paradium, emprically on unconditional convergence and econometrically on GMM estimators.

\subsection{Literature Review}

Here, the theoretical and empirical literature and conceptual frame work of the study are brefly discussed.

\subsubsection{Theoretical Literature}

Foreign capital often takes two main forms: private foreign investment and foreign aid. Foreign private investment can also be foreign direct investment and portfolio investment ( Ilhan,2007; Lamine, 2010). Organization for economic cooperation and development (OECD) defines FDI as:

Foreign direct investment reflects establishing a lasting interest by a resident enterprise in one economy (direct investor) in an enterprise (direct investment enterprise) that is resident in an economy other than that of the direct investor. The lasting interest implies the existence of a long-term relationship between the direct investor and the direct investment enterprise and a significant degree of influence on the management of the enterprise. The direct or indirect ownership of 10\% or more of the voting power of an enterprise resident in one economy by an investor resident in another economy is evidence of such a relationship ( OECD, 2008, 48).

Different types of FDI are identified based on various criteria. Based on the strategic motive of investment, FDI is classified as market-seeking FDI, resource-seeking FDI, efficiency-seeking FDI and strategic asset seeking FDI (Kinyondo, 2012 ; Ilhan,2007; Spatz, 2004). Furthermore, there are horizontal, vertical, and diversified FDI depending on the scope of activity (Beugelsdijk \& Zwinkels, 2008). Based on investment strategy, FDI can be greenfield investment, brownfield investment, cross-boarder merger and acquisitions, and joint ventures (UNCTAD, 2013a; Esso, 2010; Kinyondo, 2012 ; Rajan, 2004; Solomon, 2008).

The recent theories of FDI include; product life cycle theory, monopolistic-advantage theory, internalization theory, and the eclectic paradigm (Solomon, 2008;Assefa, 2006; Patterson, et. al, 2004; Dunning, 1993). But, this study was focused on the Ecletic Theory. The eclectic paradigm offers a general framework for explaining international production. Dunning's OLI framework combines three advantages which motivates FDI: Ownership advantage (O), Location advantage(L) and Internalization advantage(I) (Dunning, 1993; Dunning, 2000). It links a macroeconomic theory of international trade $(\mathrm{L})$ and a microeconomic theory of the firm $(\mathrm{O} \& \mathrm{I})$. The key assertion is that all three factors are 
important in determining the extent and pattern of FDI. Ownership-specific advantages refers to firm's access to tangible assets such as natural endowments, manpower, and capital; and intangible assets such as technology and information, managerial, marketing, and entrepreneurial skills, and organizational systems to which other firms do not have access (Gattai, 2006; Soci, 2002). Location-specific advantage corresponds to the factor endowments introducing a market structure, government legislation and policies, and the political, legal, and cultural environments in which FDI is undertaken. Finally, Internalization advantage explains firm's inherent flexibility and capacity to operate.The eclectic paradigm provides more comprehensive view of explaining FDI than the product life-cycle theory, the monopolistic advantage, or the internalization theory. OLI model integrates country specific, ownership-specific, and internalization factors in articulating the logic and benefits of international production (Dunning, 1993; Dunning, 2000).

FDI and economic growth are closely related. The theoretical foundation of FDI is the classical international trade theory of comparative advantage (David Ricardo) and differences in factor endowments (Heckscher-Ohlin model) between countries (Sala \& Trivin, 2014;Assefa, 2006). Furthermore, the importance of capital to an economy has been well stated in Keynesian, neoclassical and endogenous growth theories. Following the US great depression of 1930s, the Keynesian growth model came into existentence with the assumptions that output is proportional to the stock of capital and factor inputs (Balasubramanyam, 1996). The Solow's neoclassical growth model suggests that FDI increases capital stock and growth in a host economy through enhancing capital formation. According to neoclassical growth models with diminishing returns to capital, FDI has only a short-run growth effect as countries move towards a new steady state. Contrarily, endogenous growth theory assumes that FDI is more effective than domestic investment as it incorporates new technologies in the production function (Romer, 1990; 1994). It asumes that FDI associated technological spillovers offset the effects of diminishing returns to capital and keep the economy on a long-term growth path(Kotrajaras, 2010; Ozturk, 2007). Endogenous growth literature identifys two distinct approaches that incorporate human capital into economic growth models. The first approach regards the accumulation of human capital as an engine of growth (Ibid, Nelson, 1966) while,the second approach emphasizes the role of human capital stock in the process of innovation and adoption of new technologies (Ibid).

Most recently, the new growth theories aknowledge the importance of FDI to commence economic growth through financing new investment and technology transfer ( Sala \& Trivin, 2014). Unlike the previous ones, the new growth models (Romer-Lucas models) emphasize the role of research and development, human capital accumulation and externalities on economic growth.

Extending engogeneous growth model, economic convergence hypothesis states the contribution of FDI. There are two types of economic convergences; unconditional (absolute) convergence and conditional (relative) convergence (Sara \& Trivin ,2014). Unconditional convergence occurs when poor countries grow faster than rich ones independent of the political and socioeconomic factors. The relative economic convergence is about diminishing the existing differences in income between relatively similar countries or regions (Havlik, 2013; Lucas, 1988). Indeed, we do not assume perfect similarity in growth levels between EA countries, but, the prolonged socioeconomic \& other linkages matter (Kaitila, 2005). FDI has non-linear effect on economic growth, and its effect is conditioned by multiple host and home country related variables.

\subsubsection{Empirical Literature}

Some empirical evidences reveal FDI as crucial to economic growth. Others argue that the effect of FDI depends on degree of complementarity and substitution between FDI and domestic investment, macroeconomic stability, institutional and legal framework, knowledge and human capital, trade openness, and other socioeconomic and demographic characteristics ( Agrawal, 2011,2015;Sala \& Trivin, 2014; Alege \& Ogundipe, 2013; Abadi, 2011; Lamine, 2010; Beugelsdijk \& Zwinkels, 2008;). Generally, the empirical evidences show different results; positive , marginal, negative, and neutral effects of FDI on growth.

Among empirical works found positive effect of FDI on economic growth are; DeMello (1997), Obwona (2001), Ayanwale (2007), Sala and Trivin (2014); Agrawal (2015). Similarly, Sukar et. al. (2004) and Akinlo (2004) sought a marginal contribution of FDI to growth. Still other researchers argue that the effect of FDI on economic growth is not an automatic effect, but it depends on various country specific factors. For similar argument, DeMello (1997), Blomstrom et al. (2000), and UNCTAD $(1998,2008$, and 2013) pointed that the effect of FDI on growth is directly related to the level of development of a host country (Abdul, 2007 ).

Other studies also revealed that the effect of FDI on economic growth depend on the level of human capital (Abdalla, 2013; Sukar \& Hassan, 2007; Borensztein, 1998). Recently, UNCTAD (2013) and other studies (Sala \& Trivin, 2014; IMF, 2009) suggest that the positive effect of FDI depend on openness to international trade. FDI can broaden access to export markets by using foreign firms as channels to distribute goods in foreign markets through created global trade experience and networks. 
Contrarily, Alege \& Ogundipe (2013), found a negative effect of FDI on economic growth in ECOWAS region. He added that the incidence of negative effect gets stronger with the level of under development; growth stimulating effect of FDI depends on human capital, quality of institutions, infrastructure and other country specific factors.

Sukar and Hassan (2011) investigated "the effects of foreign direct investment on economic growth: the case of sub-Sahara Africa" by using 25 years panel data over the period 1975-1999. Thus, they found marginally significant positive effect of FDI on economic growth.

Recently, Sala and Trivin (2014) studied on the "Openness, Investment and Growth in Sub-Saharan Africa". They used OLS regression and GMM method to estimate the dynamic growth model from panel data ( 1980-2009); examined both conditional and unconditional convergence model.The finding was that globalization (trade openness) and FDI have significant effect on economic growth in the past three decades.

Agrawal (2015) analyzed "Foreign Direct Investment \& Economic Growth in BRICS Economies: A Panel Data Analysis. He focused on cointegration and causality analysis at panel level which indicated the presence of long run relationship between FDI and economic growth in BRICS.

\subsubsection{Conceptual Frame Work}

The conceptual frame work (see figure 1.1) was designed from theoretical basis, practical observations and empirical evidences. Dunning's eclectic (OLI) paradigm is my theoretical base, which is dominant analytical frame work for accommodating various determinants of FDI. OLI model explains foreign production from three interdependent variables. Ownership advantage $(O)$ asserts how foreign firms enjoy competitive advantage relative to domestic firms. Location advantage (L) of firms is determined by natural resource endowments; market size; assets (skilled labor, technology \& infrastructure); and the subregion's regulatory and policy position. Internalization advantage (I) assesses how firms create and use their core competencies, given the location attractions of EA countries. Foreign firms invest in host countries mainly to exploit such advantages with prifit maximization motive. Regulatory and policy position determines the level of investment, production and economic growth of EA. Indeed,domestic and international investment policies affect the level of FDI. Furtherrmore, the macroeconomic stabilization such as fiscal and monetary policies, tax system, etc determine the level of investment and growth. The current economic condition of Eastern Africa, and the existing resource gap justifies the practical relevance of FDI. Thus, I assume that FDI directly affects economic growth and indirectly other growth determinants that are shown in the model.

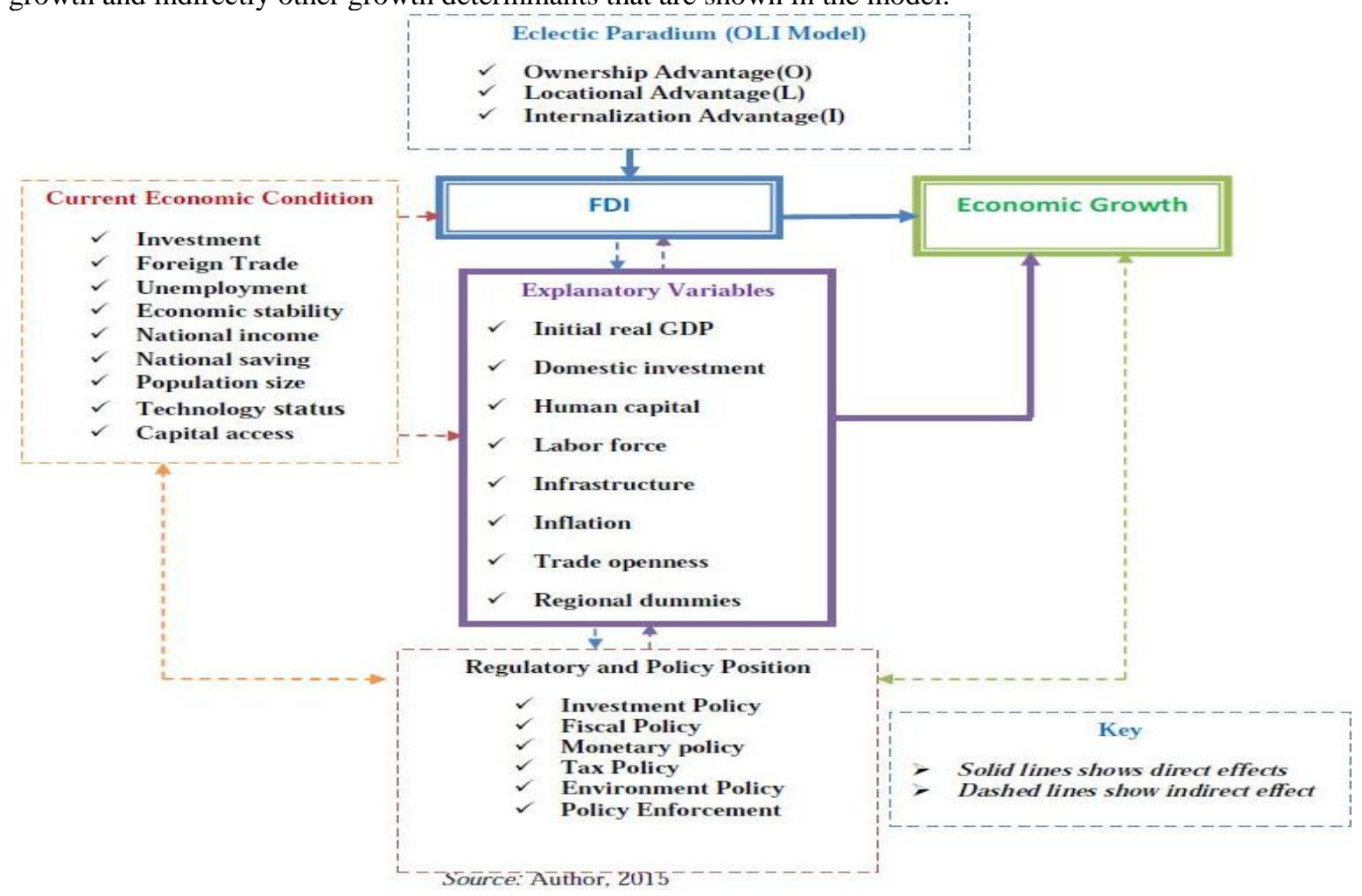

Source: Author, 2015

Figure 1.1 The Impact of FDI on Economic Growth 


\subsection{Hypotheses}

Basically the study attempted to examine wheaher FDI significantly contributes to economic growth, and wheather there is economic conditional convergence in Eastern Africa (EA). Depending on the purpose, literature review and observations, three points were hypotheized to be tested statistically. First, FDI will have positive and significant impact on economic growth in EA. Second, FDI does not crowd out domestic private investment in EA. Third, there will be an economic conditional convergence in EA countries.

Both assumptions are supported by growth theories (kenesian, classical, neoclassical,endogenous) international institutions (WB, UNCTAD,AfDB) and empirical evidences. Conditional convergence theory (Mankiw,1992) argues that countries or group of countries can converge to their steady state level of income in the long run. By implication we assume that EA countries (having similar economic condition) can conditionally converge to their steady state if they are exposed to some similar intervention or treatement( in our case receive FDI).

\section{Methodology}

The Generalized Methods of Moments (GMM) technique was used to estimate 34 years panel data from 14 EA countries.The design is berifely presented as follows.

\subsection{Population and Sample}

The United Nations Conference on Trade and Development (UNCTAD) classification was used to determine the sample, since it provides easier access to organized data (individual \& regional). Based on UNCTAD classification, Eastern Africa comprises eighteen (18) countries namely; Burundi, Comoros, Ethiopia, Kenya, Madagascar, Malawi, Mauritius, Mozambique, Seychelles, Rwanda, Uganda, Tanzania, Zambia, and Zimbabwe, Djibuti, Eritria, Sumalia, and South Sudan . However, the last four countries were not included in the main study because of data shortage. Therefore, the first fourteen (14) countries were included in the econometric analysis, since they have suffiecnt data.

\subsection{Data Source and Its Process}

The data was obtained from international sources incuding UNCTAD statistics, International Monetary Fund (IMF), and World Development Indicators (WDI) of World Bank. The study has used 34 years panel data ranging from 1980-2013 for 14 Eastern Africa counties. The data was estimated in two forms ; balanced annual data and standard five yesrs average data. The estimated none-overlapping five-year average data was designed to deal with possible endogenity among regressors, effects of business cycle, and to capture the effect of non-immediate responding variables like human capital and infrastructure ( Sala \& Trivin,204). As a result, seven waves were estimated for both the dependent and independent variables. Furthermore, stock FDI was used for regression analysis, because stock FDI is relatively stable than flow FDI.

\subsection{Definition of Variables}

Unlike some studies ( Agrawal, 2015; Alege and Ogundipe, 2013;Njoupouognigni, 2010), this study included many explanatory variables and regional dummies. The dependent variable is growth of per capita real GDP, while the explanatory variables include initial per capita real GDP, Y; Foreign direct investment ,FDI; and others ( see table 2.1). However, some important variables such as political risk index, good governance, financial crisis, real exchange rate were not included due to lack of data. Conditional convergence is measured from initial per capita real GDP and its lags (Bichaka Fayissa, 2008). For more information,refer table 2.1.

Table 2.1. Definition of Variables

\begin{tabular}{|c|c|c|c|}
\hline Variable & Definition or Description & Sign & Source \\
\hline $\mathrm{Y}$ & $\begin{array}{l}\text { Annual percentage growth rate of per capita real gross domestic } \\
\text { product for country } i \text { at time } t \text {. }\end{array}$ & or $^{+}$ & WDI/WB \\
\hline $\ln \mathrm{Y}$ & $\begin{array}{l}\text { Natural logarithm of initial per capita real gross domestic product } \\
\text { (constant } 2005 \text { US } \$ \text { ) for country } i \text { at time t. }\end{array}$ & $\begin{array}{l}+ \\
\text { or - }\end{array}$ & WDI/WB \\
\hline FDI & $\begin{array}{l}\text { Foreign direct investment ( stock) inflows as percentage of GDP } \\
\text { for country } \mathrm{i} \text { at time t. }\end{array}$ & + & UNCTAD \\
\hline DI & $\begin{array}{l}\text { Domestic private investment-gross fixed capital formation as } \\
\text { percentage of GDP of host country } i \text { at time } t \text {. }\end{array}$ & + & WDI/WB \\
\hline $\mathrm{HC}$ & $\begin{array}{l}\text { Human capital-primary school enrollment as percentage of gross } \\
\text { total enrollment for country } i \text { at time } t \text {. }\end{array}$ & + & WDI/WB \\
\hline $\mathrm{LF}$ & $\begin{array}{l}\text { Labor force- the number of people aged between } 15-64 \text { as } \\
\text { percentage of total population for country } i \text { at time t. }\end{array}$ & + & WDI/WB \\
\hline INFRA & $\begin{array}{l}\text { Infrastructure-the number of mobile cellular subscription Per } \\
\text { hundred (100) person for country } \mathrm{i} \text { at time } \mathrm{t} \text {. }\end{array}$ & + & WDI/WB \\
\hline OPEN & $\begin{array}{l}\text { Openness-the sum of export and import value as percentage of } \\
\text { GDP for country } i \text { at time } t \text {. }\end{array}$ & + & WDI/WB \\
\hline INF & Inflation- Annual GDP deflator in percent for country $i$ at time $t$. & - & WDI/WB \\
\hline DIGAD & Dummy variable for intergovernmental authority on development. & + & AU \\
\hline
\end{tabular}


It takes 1 if the country is a member of IGAD and 0 otherwise.

DEAC Dummy variable for Eastern African community. It takes 1 if the country is a member of EAC and 0 otherwise.

DCOMESA Dummy variable for common markets for Eastern and Southern Africa. It takes 1 if the country is a member of COMESA and 0

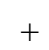

$+$

AU

$\mathrm{AU}$ otherwise.

Source: Author, 2015 ( Compiled from WDI,UNCTAD, AU), AU- African Union

\subsection{Econometric Model Specification}

Foreign direct investment is required to rduce the capital gap and hence income gap between developing and developed countries (Romer, 1986, 1990, 1994). Under endogenous growth view, FDI impacts growth trough improving the productivity of domestic and foreign resources (DeMello, 1997; Alege \& Ogundipe, 2013; Sala \& Trivin, 2014), hence, the relation between FDI and economic growth can be framed from augmented Cobb-Douglas production function as follows:

$$
\mathrm{Y}=\mathrm{f}\left[\mathrm{K}_{\mathrm{d}}, \mathrm{K}_{\mathrm{f}}, \mathrm{L}, \mathrm{E}\right]=\mathrm{A} L^{\alpha} K^{\beta} E^{[1-\alpha-\beta]}
$$

Where; $\mathrm{Y}$ is growth of output, $\mathrm{K}_{\mathrm{d}}$ is domestic capital, $\mathrm{K}_{\mathrm{f}}$ is foreign capital, $\mathrm{L}$ is labor, $\mathrm{E}$ is the spillover effect from FDI, $\alpha$ and $\beta$ are the elasticity of labor and capital to output (Y) respectively, and A refers efficiency of production.

Human capital augmented Lucas model (Lucas, 1988, Romer, 1994) divides labor in to human capital (HC) and raw labor (LF) based on its productivity. Furthermore, the rate of economic growth is affected by the stock of capital $\left(\mathrm{Y}_{0}\right)$, the level of infrastructure (INFRA), inflation (INF), foreign trade (OPEN) and institutional factors (Sukar \& Hassan , 2011; Alege \& Ogundipe, 2013; Sala \& Trivin, 2014; AfDB, 2014). In our case, the institutional factors are regional dummies (RD) include, IGAD, EAC \& COMESA.

In line with the endogenous growth assumption, the above growth determinants are augmented in to equation (1) to yield the implicit growth equation:

$$
\mathrm{Y}=\mathrm{f}\left[\mathrm{Y}_{0} \text {, FDI, DI, HC, LF, INFRA, OPEN, INF, RD, } \varepsilon\right]
$$

Where; $\mathrm{Y}$ is growth of output, $\mathrm{Y}_{0}$ is stock of capital, FDI is foreign direct investment, $\mathrm{HC}$ is the human capital, LF is the labor force, INFRA is infrastructure, OPEN is the value of foreign trade, INF is the rate of inflation, RD is regional dummies, and $\varepsilon$ is the general error term.

Since the relationship between growth of output (dependent variable) and independent variables is non-linear, the explicit form of the model given in equation (2) can be rewritten as:

$$
\mathrm{Y}=\mathrm{Af}\left[\mathrm{Y}_{0}^{\beta_{1}} \quad \mathrm{FDI}^{\beta_{2}} \quad \mathrm{DI}^{\beta_{3}} \mathrm{HC}^{\beta_{4}} \mathrm{LF}^{\beta_{5}} \mathrm{INFRA}^{\beta_{6}} \mathrm{OPEN}^{\beta_{7}} \quad \mathrm{INF}^{\beta_{8}} \quad \operatorname{IGAD}^{\beta_{9}} \mathrm{EAC}^{\beta_{10}} \mathrm{COMESA}^{\beta_{11}} \varepsilon_{]}\right]^{(3)}
$$

Where; $\mathrm{Y}_{0}$ is a stock of capital; $\beta_{1} \beta_{2} . ., \beta_{11}$ are respective factor contributions to growth; $\varepsilon$ is error term.

As panel models comprise both longitudinal and cross sectional data, it has dynamic dimensions across space, time, and variables (Wooldrigge, 2005). In our case, there are 14 cross countries, 34 years data and 11 variables. Therefore, equation (3) is further modified to include cross sectional units and time horizon explicitly. Thus, the dynamic cross-country growth model is given as:

$$
\left.\mathrm{Y}_{i t}=\mathrm{Af}_{\left[\mathrm{Y}_{i t-1}^{\beta_{1}}\right.} \mathrm{FDI}_{i t}^{\beta_{2}} \quad \mathrm{DI}_{i t}^{\beta_{3}} \mathrm{HC}_{i t}^{\beta_{4}} \mathrm{LF}_{i t}^{\beta_{5}} \quad \mathrm{INFRA}_{i t}^{\beta_{6}} \mathrm{OPEN}_{i t}^{\beta_{7}} \quad \mathrm{INF}_{i t}^{\beta_{8}} \quad \operatorname{IGAD}_{i t}^{\beta_{9}} \quad \operatorname{EAC}_{i t}^{\beta_{10}} \mathrm{COMESA}_{i t}^{\beta_{11}} U_{i t}\right](4)
$$

Where; i refers cross-sectional units, i.e. countries; $\mathrm{t}$ refers is time units ,in years which ranges from 1980-2013; $U_{i t}$ is the composite disturbance term which includes: $\mu_{i}$ is the unobservable country specific effects, $v_{t}$ refers time specific effects, and $\varepsilon_{i t}$ refers the idiosyncratic error term.

For computational convenience and easier understanding, the non-linear equation is converted in to linear equation trough logarithmic transformation as follows:

$$
\begin{aligned}
& Y_{i t}=\beta_{0}+\beta_{1} \ln Y_{i t-1}+\beta_{2} F D I_{i t}+\beta_{3} D I_{i t}+\beta_{4} H C_{i t}+\beta_{5} L F_{i t}+\beta_{6} I N F R A_{i t}+\beta_{7} \text { OPEN }_{i t} \\
& +\beta_{8} I N F_{i t}+\beta_{9} I G A D_{i t}+\beta_{10} E A C_{i t}+\beta_{11} C O M E S A_{i t}+U_{i t}
\end{aligned}
$$


Where; $\beta_{0}$ is the intercept; $\beta_{2,} \beta_{3}, \ldots, \beta_{11}$ are coefficients of respective explanatory variables; $\beta_{1}$ is the coefficient of conditional convergence $Y_{i t}$ is the growth rate of per capita real GDP-the dependent variable; $\ln Y_{i t}$ is first lag natural logarithm of per capita real GDP; others as defined in table 2.1.

Checking the existence and rate of economic convergence is our objective. Absolute convergence (sigma, $\delta$ ) occurs when poor countries (regions) grow faster than rich countries independent of the political and socioeconomic structure of each country (Young, et. al., 2008). This real convergence may narrow down differences in economic growth between poor and rich countries or regions (Havlik, 2013; Lucas, 1988). Literature (Sala \& Trivin, 2014) empirically detecte absolute convergence when the estimated coefficients of initial income is negative from a univariate equation. Unconditional convergence is checked by using the dynamic growth model:

$$
Y_{i, t}=\alpha_{i, t}+\beta_{1} Y_{i, t-1}+\varepsilon_{i, t}
$$

Where, $Y_{i, t}$ is the natural log difference of per capita real GDP is, and $Y_{i, t-1}$ is the lagged natural logarithm of per capita real GDP. However, such model is criticized due to the inherent problem of omitted-variables bias (Sala \& Trivin, 2014). For example, our variable of interest-FDI is not included in the model (equation 6) and since countries are from the same economic region (EA); it seems not apropriate model for us.

Conditional (beta, $\beta$ ) convergence is found when an economy or group of economies move towards its/their own long run steady-state income level, which is determined by the political and socio-economic structure of an economy or group of economies (Ibid) . Technically, $\beta$ convergence occurs when there is a negative relationship between the initial per capita GDP and growth of GDP by controlling covariates (Kaitila, 2005). Conditional convergence is estimated in a multivariate regression, which augments country specific, time specific, and random effects to yield the standard dynamic growth model of the form:

$$
Y_{i, t}=\beta_{0}+\beta_{1} Y_{i, t-1}+\delta X_{i, t}+\mu_{i}+v_{t}+\varepsilon_{i, t}
$$

Where; $\beta_{0}$ is intercept to be estimated; and $\beta_{1}$ is a conditional convergence rate to be estimated; $X_{i, t}$ is a row vector of growth determinants, $\mu_{i}$ is a country specific fixed-effects that controls for time-invariant differences across countries that are not controlled by regresses,$X_{i, t} ; v_{t}$ is time fixed-effects controlling for temporary shocks common across countries; and $\varepsilon_{i, t}$, is an idiosyncratic error which is usually independent of both the regressors, $X_{i, t}$ and the individual error component, $\mu_{i}$, and hence it has a zero mean white-noise residual.

One can employ both balanced annual panel data and five years average panel data to estimate growth models. However, estimating growth models by using only annual data may result in two biases; the problem of potential endogenity among covariates and uncounted country specific effects (Sala \& Trivin, 2014; Barro, 2000, 1991; Beck, 2000). Therefore, as standard practice, we took none-overlapping five-year average data to deal with expected endogenity problem among explanatory variables, business cycles effects, to capture the effect of non-immediate responding variables (such as human capital \& infrastructure in our case). So, the analysis from five year average panel data focuses on the long run situations; to include this, equation (7) is slightly modified as follows:

$$
Y_{i, t}=\beta_{0}+\beta_{1} Y_{i, 0}+\delta X_{i, t}^{\prime}+\mu_{i}+v_{t}+\varepsilon_{i, t}
$$

Where; $Y_{i, 0}$ is the initial per capita real GDP (for each five-year period), \& $\beta_{0}$ is the conditional convergence rate.

The advantage of using five years average is twofold. First, the variables available only for five year periods are good proxy for true unobserved effects .Second, business cycle effects may adversely influence economic behaviors; for example, adaptive expectations on inflation often lead to irrational business decisions and such effects can be removed trough this technique. Furthermore, since the length of business cycle is usually the same, its effect is also identical across countries.

\subsection{Additional Models}

By adapting synergy analysis on merger and acquisition made by Corson, et. al. (2004), additional interactive growth models are developed with the assumption that synergy effect of covariates would influence growth. As a result, equation (7) captures the combined effect of FDI and the rest repressors, $X_{i, t}^{\prime}$ on the dependent variable, $Y_{i, t}$. Again, the growth impact of FDI with and without other important covariates will not be the same. Indeed, literature recognizes the role of factor interdependences in influencing economic growth (UNCTAD, 2012, 2014; Abdalla, 2013). For example, 
well developed infrastructure attracts more foreign firms than otherwise; availability of competent human capital speeds he return from investment, etc, ceteris paribus. So, examining the combined effect of all regressors was needed.

Equation (9) shows the combined marginal effect of all covariates on economic growth ( Sala \& Trivin, 2014). It is computed by following five procedures; (1) perform formal regression on equation (7); (2) take the sum of all coefficients of right hand side variables included in the model to find weighted coefficient, (3) multiply this weighted coefficient with FDI, and (4) regress weighted value of covariates on Y; (5) finally, identify \& analyze the resulting estimators as combined marginal effects on the rate of growth. The combined effects growth model is given as:

$$
\bar{y}_{i, t}=\omega_{0}+\omega_{1} \ln \bar{y}_{i, t-1}+\omega_{2} \overline{f d i}_{i, t}+u_{i}
$$

Where; $\bar{y}_{i, t}$ is the estimated growth rate of per capita real GDP; $\omega_{0}$ is the weighed constant intercept; $\omega_{1}$ is the combined conditional convergence term; $\ln \bar{y}_{i t}$ is the weighted initial per capita real GDP; $\omega_{2}$ is the combined effect of FDI together with other repressor's on the growth rate of per capita real GDP; and $\overline{f d i}_{i, t}$ is the weighted foreign direct investment as percentage of GDP.

Furthermore, we have formulated the paired effects model of three variables on the growth rate of the Eastern Africa. The purpose is to examine the mutual effects of two variables on the economic growth (Y-gpcrgdp). The variables are foreign direct investment (FDI), gross domestic investment (DI) and trade openness (OPEN). During estimation, FDI is first multiplied with both DI \& OPEN separately; include convergence term and then regressed against per capita real growth, $\mathrm{Y}$. The paired effects growth model is estimated from the equation:

$$
y_{i, t}=\lambda_{0}+\lambda_{1} Y_{i, t-1}+\lambda_{2} f d_{i, t}+\lambda_{3} f_{o p}+\lambda_{t, t} \text { dop }_{i, t}+u_{i, t}
$$

Where, $\lambda_{0}$ is the constant term, $\lambda_{1}, \lambda_{2}, \lambda_{3}, \lambda_{4}$ are coefficients of the product of FDI and domestic investment (fd); FDI and trade openness (fop); and domestic investment and trade openness (dop) respectively.

2.6 Estimation Technique: GMM

This paper has maximized the advantage of panel data analysis by using dynamic estimation techniques over linear, fixed and random effects methods. The dynamic panel estimation methods like GMM address the three inherent estimation problems namely, endogenity of regressors, omitted variables and measurement errors (Agrawal, 2015; Sala \& Trivin, 2014; Alege \& Ogundipe, 2013; Wooldridge, 2001). GMM is general framework for deriving estimators that are consistent under weak distributional assumptions.

Therefore, "difference-GMM" developed by Arellano \& Bond (1991), and "system-GMM" developed by Arellano \& Bover (1995) and Blundell \& Bond (1998) are widely used. Panel data can be analyzed by using pooled OLS, random effect model, and fixed effect models independently,however, they are limitatted with respect to this study.

The common assumption in linear regression is that the regressors are orthogonal to the errors. Meaning the moments of regressors with the errors are set to zero; i.e. each explanatory variable, $X_{j}$ is uncorrelated with the error term, $\varepsilon_{i, t}$; i.e. $E\left(\varepsilon_{i, t} / X_{i, j}\right)=0$. But, this assumption doesn't hold in the growth models since regressors are expected to be correlated with error term. For instance, infrastructure often affect both the dependent and independent variables (Wooldrigge,2001).Thus, OLS is not appropriate technique in our case.

The standard fixed effects (FE) model assumes that the observed covariates and time-varying errors have zero means, constant variances and zero correlations. This strict exogeneity assumption is crucial for consistency of the fixed effects estimator (Roodman, 2009; Wooldrigge, 2005). However, panel growth models are conditional on the observed and unobserved effects.

First differencing (or first fixed transformation) is used (Alege \& Ogundipe, 2013) to eliminate the country specific fixed effects, $\mu_{i}$ as follows:

$$
y_{t}-y_{i, t-1}=\beta_{1}\left(Y_{i, t-1}-Y_{i, t-2}\right)+\delta^{\prime}\left(X_{i}-X_{i, t-1}\right)+\left(\varepsilon_{i}-\varepsilon_{i, t-1}\right)
$$

The lagged dependant variable, $Y$ (see equation 11) is still endogenous.

Infact, in dynamic growth models, fixed effects technique would not give consistent estimates and recently another estimation method called Generalized Methods of Moments (GMM) has been used. In order to address the expected endogeneity problem, Arellano and Bond (1991) developed the Difference Generalized Methods of Moments (DGMM) methods. The possible instruments are explanatory variables having lag length two second and above periods (lag length, $\mathrm{P}>=2)$. That is mathematically proved; by relaxing equation (11), the natural candidates for $\left(y_{i, t-1}-y_{i, t-2}\right)$ are $y_{i, t-2}$ and $\left(y_{t, t-2}-y_{i, t-3}\right)$ because both terms relate with $\left(y_{i, t-1}-y_{i, t-2}\right)$ but do not correlate with the error term $\left(\varepsilon_{i}-\varepsilon_{i, t-1}\right)$ as long as stochastic error, $\varepsilon_{i, t}$ is not serially correlated.

Despite all these efforts, the first DGMM may yield inefficient estimates if one uses balanced annual time series data from small sample and when lagged dependent (L.Y) variable is used as independent variable, even if the residuals are not serially correlated. 
To overcome the above limitations of DGMM, Arellano and Bover (1995) and Blundell and Bond(1998) developed another method called System Generalized Methods of Moments (SGMM), which incorporates additional assumption to classic Arellano \& Bond (1991), where first differences of instrumental variables are uncorrelated with the fixed effects (Roodman, 2009). Hence, Arellano and Bover (1995) developed system of equations, which allows use of more information from observations. Regressors, X's may contain endogenous variables, weak and strictly exogenous variables. We have additional moment conditions such as weak exogenous variables (growth of per capital real GDP, Y). Weakly exogenous variables or week explanatory variables are not strictly endogenous variables. Therefore, Arellano and Bover SGMM estimators can improve efficiency of the Arellano and Bond estimators shown in equation (7) by incorporating as many instruments as follows:

$$
\begin{aligned}
& \left\{\left[Y_{i, t-p}\left(\varepsilon_{i, t}-\varepsilon_{i, t-1}\right)\right]=0\right. \\
& \left\{\left[X_{i, t-p}\left(\varepsilon_{i, t}-\varepsilon_{i, t-1}\right)\right]=0\right. \\
& \text { and for } \mathrm{P}>=2 ; \mathrm{t}=3, \ldots \mathrm{T}
\end{aligned}
$$

Where, $\mathrm{p}$ is the number of lags or moments and $\mathrm{t}$ is the number of time; which ranges from 3 to $\mathrm{T}$

Blundell and Bond (1998) further developed new approach that transforms the instruments to make them exogenous to the fixed effects instead of transforming the explanatory variables. This approach is feasible approach since changes in any of instrumenting variables are uncorrelated with the fixed effects in equation (8). Mathematically, the modification is shown as:

$$
\begin{aligned}
& \left\{E \left[Y_{i, t+p} \cdot \mu_{i}=E\left[Y_{i+q} \cdot \mu_{i}\right]\right.\right. \\
& \left\{E\left[X_{i, t+p} . \mu_{i}\right]=E\left[X_{i+q} \cdot \mu_{i}\right] \text { for all } \mathrm{p} \text { and } \mathrm{q}\right.
\end{aligned}
$$

Where, $\mathrm{p}$ is the lag length determined by Akaike information criteria (AIC) and Schwarz Bayesian (SC) information criteria; $\mathrm{q}$ is the population moment conditions. In equation (11), $E\left[Y_{i, t+p} . \mu\right]$ and $\left.E\left[Y_{i, t} \cdot \mu\right]\right]$ become time-invariant. In this case, $\left(y_{i, t-1}-y_{i, t-2}\right)$ is a valid instrument for $y_{i, t}$ and $X_{i, t}$.

The SGMM considers both level and differenced variables of pre-determined and endogenous variables and even the dependent variable could depend on its past realizations. Following this, the dynamic growth equation given in equation (7) can be written as:

$$
\Delta Y_{i, t}=\beta_{0}+\beta_{1} \Delta Y_{i, t-1}+\delta \Delta X_{i, t-1}+\lambda Z_{i, t}+U_{i, t}
$$

Where, $\Delta Y_{i, t}$ is the first difference of the natural logarithm of the dependent variable (Y) in country i at time t; $Y_{i, t-1}$ is the lagged difference of the dependent variable; $X_{i, t-1}$ is a vector of lagged level and differenced pre-determined and endogenous variables; $Z_{i, t}$ is a vector of endogenous variables; and $\beta_{1}, \delta$, and $\lambda$ are estimated parameters; and $U_{i, t}$ is the composite disturbance terms.

Generally, although both the DGMM and SGMM were estimated, the analysis mainly used System GMM since it give more consistent and efficient estimators. This doesn't mean that GMM estimators are perfect, so statistical test is important (Wooldridge, 2001). Arellano and Bond (1991) suggested two specification tests for GMM estimators. First, the Sargan/Hansen tests of over-identifying tests are made to check joint validity of the instruments. The null hypothesis is that the instruments are not correlated with the residuals. Second, autocorrelation test, examines the hypothesis that the idiosyncratic disturbance term, $\varepsilon_{i, t}$ is not serially correlated. Besides checking for the fixed effects, the Arellano-Bond test is used for residuals in difference. But, the first-order serial correlation test in differences is not sufficient. So, the second-order correlation in differences is applied to check the first-correlation in levels. According to Roodman (2009), in order to check for serial correlation of order p in levels, we look for correlation of order $(p+\cdot)$ in differences. Accordingly, tests were undertook and proved that the estimators as consistent and efficient.

\section{Results and Discussion}

The econometric analysis used GMM estimators computed by using STATA 13 software. Table 3.2 presents summarized results of GMM estimators. The effect of FDI on economic growth in the sub-region is positive and significant at $10 \%$ significance level. Most of other control variables are directly related to the growth rate of per capita real GDP. The finding is consistent with some studies (Zakari et.al.,2012; Alege \& Ogundipe, 2013; Sala \& Trivin, 2014; Agrawal, 2015;WEF,2015; Lenka \& Sharma, 2015) ;etc ). In the short run, human capital and infrastructure were negatively related to per capita GDP growth rate. Since human capital and infrastructure is still poor in EA , the result justfies the reality of the sub-region. 
The estimated coefficients of the first lag of natural logarithm of intial percapital real GDP ( $\left.\operatorname{L} . \operatorname{LnY} \mathrm{Y}_{0}\right)$ are negative and significant both in annual panel (short run) and five years average panel ( long run), indicating the existence of conditional convergence in the sub-region. The rate of conditional convergence in the first lag ranges from $4.3 \%$ to $6 \%$. Particularily, the speed of convergence is estimated at $6 \%$ per year and $4.3 \%$ per five years average to the first lags of per capita real income. This figure is comparable with sub-Saharan African countries as Sala and Trivin (2014) found the speed of conditional convergence at $4 \%$. This indicates that on average the speed of conditional convergence of Eastern Africa (EA) countries is higher than Sub-Saharan Africa (SSA) countries; due to the existence of socioeconomic, political, and historical interdependence among EA than SSA (Adb, 2013).

The mobilization of foreign and domestic resources (if not sufficient) in the subregion have improved which can be justified by the contribution of FDI and domestic private investment to the rate of economic growth. On one hand, the effect of FDI on economic convergence is significant, as it affects the rate of growth significantly. FDI could provide employment for the ever growing labor and might expand its income.

Past growth realization in the growth model is captured by the first lag of per capita real GDP coefficient (L.Y). The negative sign shows the existence of economic convergence to their steady state income. Eastern African economies converge to their last year's growth rate in real terms at 3\% per year and at 5\% on five year's average (see column 3 and 5 of table 3.2). Explicitly this means that the higher the growth rate in previous years, the higher the growth rate in the current year would be, and the lower the rate of growth in previous years the lower the growth rate this year would be. Why past realization? This is due to consumption and production interdependence; geographical, political, socio-cultural, institutional and economic interdependencies because the growth rate of one country both affects and is affected by the growth rate of other country in the study area. It is consistent with studies like Alege \& Ogundipe (2013).

The finding also revealed that domestic private investment (DI) is one of the growth contributors and is not crowed out by the FDI. However, domestic investment is not significant during initial stages of growth and significant in the long run. We have ample theoretical justifications (UNCTAD, 2014; Analyse Africa,2015, etc) why this could happen enter alia; the productive capacity, the investment environment, the level of infrastructure, state of technology and knowhow of the economies is poor during earlier stages of growth.

Despite the theoretical importance of human capital to growth and development, its practical contribution to Eastern African countries is blurred in the short run, but, it is influential in the long run.

Table 3.2 Summary Results of GMM Estimators

\begin{tabular}{|c|c|c|c|c|}
\hline \multirow{3}{*}{$\begin{array}{c}\text { Explanatory } \\
\text { Variables }\end{array}$} & \multicolumn{4}{|c|}{ Dependent Variable: Y } \\
\hline & \multicolumn{2}{|c|}{ Annual Panel } & \multicolumn{2}{|c|}{5 Years Average Panel } \\
\hline & DGMM & SGMM & DGMM & SGMM \\
\hline \multirow[t]{2}{*}{ L.Y } & $-0.0338 * * *$ & $-0.0274 * * *$ & $-0.660 * * *$ & $-0.489 * * *$ \\
\hline & $(0.00564)$ & $(0.00428)$ & $(0.150)$ & $(0.127)$ \\
\hline \multirow[t]{2}{*}{ L2.Y } & 0.00463 & $0.00900 * *$ & -0.0619 & -0.0229 \\
\hline & $(0.00554)$ & $(0.00415)$ & $(0.110)$ & $(0.0745)$ \\
\hline \multirow[t]{2}{*}{$\operatorname{Ln} \mathrm{Y}_{0}$} & $0.086 * * *$ & $0.025 * * *$ & $0.080 * * *$ & $0.10 * * *$ \\
\hline & $(0.593)$ & $(0.522)$ & $(4.796)$ & $(4.141)$ \\
\hline \multirow[t]{2}{*}{ L.LnY 0} & $-0.040 * * *$ & $-0.059 * * *$ & $-0.061 * * *$ & $-0.043 * * *$ \\
\hline & $(0.680)$ & $(0.525)$ & $(4.258)$ & $(3.763)$ \\
\hline \multirow[t]{2}{*}{ FDI } & $0.0119 * *$ & $0.00507 *$ & $0.00567 *$ & $0.00179 *$ \\
\hline & $(0.00487)$ & $(0.00295)$ & $(0.0954)$ & $(0.0931)$ \\
\hline \multirow[t]{2}{*}{ DI } & 0.000935 & 0.0121 & $0.139 * *$ & $0.146 * *$ \\
\hline & $(0.00934)$ & $(0.00769)$ & $(0.0640)$ & $(0.0578)$ \\
\hline \multirow[t]{2}{*}{$\mathrm{HC}$} & -0.00384 & -0.00230 & $0.0112 * * *$ & $0.00995^{* * *}$ \\
\hline & $(0.00406)$ & $(0.00260)$ & $(0.00360)$ & $(0.00347)$ \\
\hline \multirow[t]{2}{*}{ LF } & $0.190 * * *$ & $0.189 * * *$ & -0.115 & $0.341 *$ \\
\hline & $(0.0297)$ & $(0.0217)$ & $(0.246)$ & $(0.197)$ \\
\hline \multirow[t]{2}{*}{ INFRA } & 0.00467 & $-0.00423 * *$ & $0.0431 * *$ & $0.0265^{* *}$ \\
\hline & $(0.00302)$ & $(0.00196)$ & $(0.0207)$ & $(0.0134)$ \\
\hline \multirow[t]{2}{*}{ OPEN } & $0.0167 * * *$ & $0.00657 * * *$ & $0.0255^{* *}$ & $0.0395 * *$ \\
\hline & $(0.00322)$ & $(0.00251)$ & $(0.0318)$ & $(0.0270)$ \\
\hline \multirow[t]{2}{*}{ INF } & $0.00432 * *$ & $0.00726^{* * *}$ & 0.00113 & -0.000627 \\
\hline & $(0.00197)$ & $(0.00170)$ & $(0.0228)$ & $(0.0204)$ \\
\hline \multirow[t]{2}{*}{ DIGAD } & 0.0427 & -0.273 & 0 & -3.993 \\
\hline & $(0.303)$ & (0.194) & $(0)$ & $(3.016)$ \\
\hline
\end{tabular}




\begin{tabular}{lcccc}
\hline DEAC & -0.340 & -0.0820 & 0.711 & -0.365 \\
DCOMESA & $(0.297)$ & $(0.241)$ & $(1.238)$ & $(1.264)$ \\
& -0.415 & -0.939 & $\ldots$ & $\ldots$ \\
Constant & $(0.720)$ & $(0.613)$ & $\ldots$ & $\ldots$ \\
& $5.775^{*}$ & $-4.792 * * *$ & 20.80 & $(6.539)$ \\
\hline Observations & $(3.375)$ & $(0.977)$ & & 70 \\
Number of countries & 414 & 428 & 56 & 14 \\
\hline
\end{tabular}

Standard errors in parentheses

$* * * \mathrm{p}<0.01, * * \mathrm{p}<0.05, * \mathrm{p}<0.1$

Source: Author, 2015 (from WDI \& UNCTAD Stat)

The reasons are many, to mention some;(i) usually human capital development is gained through education, which in turn takes long time (e.g. five years) to realize its return, (ii) the cost of education and hence human capital is huge, so that poor households may not afford its cost in the short run and also the government hardly provide the required education for all citizens at a time, (iii) brain drain is one of the serious challenges in the sub-region; competent productive forces are being migrated to advanced economies, (iv) the existing manpower may be placed in a wrong positions, which reduces motivation and productivity of labor. Given these pitfalls on human resource utilization, the finding rather confirm the actual situation of EA.

Labor force is the other significant determinant of growth at $1 \%$ level of significance in the short run and at $10 \%$ significance level in the long run. The long run contribution of labor ( both in foreign \& domestic sectors) is only marginal since capital intensive technologies may substitute labor or exixting lobor skill become obsolete unless necessary education and training is gained on sustainable basis. This calls for further human capital development activities in the sub region.

Conventionally, improved infrastructure provides attractive investment condition, and may lead to more production, income, and ultimately to economic growth. Infrastructure is negatively related to growth rate on in the short run (annual data), and positive and significant in the long run (5 year average data). The reason is that many people have less access to the facility; although it is improving over time. Actually infrastructure is not yet developed well in the sub-region, not only lack of financial capital but also lack of coordination between governments and other stackholders. However, in the long run both the public and private sectors may show commitment to participate in the consruction of infrastructure. Recntly, EA governments are strongly working on this area. Few examples are 6000 mega watt Ethipoain great renaissance dam (GERD) construction, Eastern African joining high way construction, and Kenya's new energy project.

Trade openness benefits small economies than large economies (Heckscher-Ohlin model) because small economies can not affect the world supply and hence world price. This means their influence to the world supply is insignificant to affect world deamnd and price levels. Small countries (Eastern Africa) are price takers in the global market. According to Krugman and Obstfeld (2006), any country gains from international trade at least in the form of comparative advantage. Although most of these countries are small to impact world market, foreign trade has benefited them significantly. Most of the time, the sub-region faces trade deficit but the contribution of trade to growth is positive and significant at $1 \%$ level. The reason could be that they import more of capital goods ( which induces investmet \& growth) than consumer goods. This signals how freign trade integration is important for continuous economic growth of the subregion.Emprically, the work of Sala \& Trivin (2014) confirms with this fnding and and that of Alege \& Ogundipe( 2013) did not.

Furthermore, the study revealed positive and significant relationship between inflation and economic growth in the short run. However, in the long run, inflation doesn't have a significant effect on economic growth. Most growth literatures suggest that less than $6 \%$ level of inflation per year induces investment in the short run (Todaro \& Smith, 2012). But, if inflation continues for long time, it may errode the confidence of new investors to enter into and dismotivate the existing ones from expanding their bsiness. Extended macroeconomic instability is bad for any economy and our investigation validated this argument. The return from investment increases when the price of good increases above its average cost of production. In the shortrun, a single digit inflation may motivate investment in Eastern Africa. The studies of Lenka \& Sharma (2015), UNCTAD (2014), Sala \& Trivn(2014), etc. supports this finding.

None of the regional dummy variables (EAC, IGAD, COMESA) have significant effect on economic growth. This implies that these institutions are not strong to influence development process of the subregion. The existing poverty and underdevelopment may also justify this result. The level of skilled manpower, the working culture, policy content and enforcement, and commitment of the governments can reduce the effect of regional integration on growth.

The combined effect of FDI and other covariates on the growth of per capita real GDP, which was not significant in the 
short-run (annual panel) and significant in long-run (five year's average panel). Two important findings were drawn from combined effects mode. First, there is an interdependence of FDI and other covariates in influencing the rate of economic growth. This implies that the performance of one variable affects the performance of the other variable in affecting the speed of growth in the short run. For instance, the rate of annual economic convergence (L.Y) declined from $6 \%$ to $5 \%$ and that of five year's average declined from $4.3 \%$ to $3.1 \%$. This shows the importance of commulative effects on growth targets. Second, the degree of combined effect of covariates varies across time period. The longer the time period, the higher the degree of combined effect on the growth would be and vice versa. This reveals that immediate economic advancement requires immediate integration. For instance, good foreign investment policy alone may not lead to expected growth target, but also good domestic investment policy, national or sectoral development policies and programs as well as the availability of sound fiscal and monetary policies.

Again, the real growth rate has converged to its long run steady state output in the first lag at $1 \%$ significance level. In the short run, the combined effct is less significant but, in the long run it is sigificant. This implies that as time gets longer and longer, the combined effect of covariates also gets stronger and stronger on the growth rate in the sub-region. From paired effects growth model indicated in equation 10, next results were obtained (see table 3.3, the last three rows).

Table 3.3 Summary Combined and Paried Effects of FDI on GDP Economic Growth

\begin{tabular}{|c|c|c|c|c|}
\hline \multirow{3}{*}{$\begin{array}{c}\text { Explanatory } \\
\text { Variables }\end{array}$} & \multicolumn{4}{|c|}{ Dependent variable: Y } \\
\hline & \multicolumn{2}{|c|}{ Annual Panel } & \multicolumn{2}{|c|}{5 Year Average Panel } \\
\hline & DGMM & SGMM & DGMM & SGMM \\
\hline \multirow[t]{2}{*}{ L.Y } & $-0.153 * * *$ & $-0.0369 * * *$ & $-0.584 * * *$ & $-0.491 * * *$ \\
\hline & $(0.0337)$ & $(0.00991)$ & $(0.0656)$ & $(0.0831)$ \\
\hline \multirow[t]{2}{*}{ L2.Y } & $-0.146 * * *$ & -0.00879 & $-0.0888 *$ & -0.0217 \\
\hline & $(0.0175)$ & $(0.0116)$ & $(0.0488)$ & $(0.0682)$ \\
\hline \multirow[t]{2}{*}{ LnY } & $0.0124 * * *$ & $0.09 * * *$ & $0.92 * * *$ & $0.60 * * *$ \\
\hline & $(0.000594)$ & $(0.547)$ & $(1.563)$ & $(1.591)$ \\
\hline \multirow[t]{2}{*}{ L.Y } & $-0.0120 * * *$ & $-0.05 * * *$ & $-0.049 * * *$ & $-0.031 * * *$ \\
\hline & $(0.000474)$ & $(0.540)$ & $(1.550)$ & $(1.560)$ \\
\hline \multirow[t]{2}{*}{ fdicom } & $0.0207 * * *$ & 0.000382 & $0.00111 *$ & $0.00166 * *$ \\
\hline & $(0.00721)$ & $(0.000372)$ & $(0.000642)$ & $(0.000787)$ \\
\hline \multirow[t]{2}{*}{ df } & $-0.000658 * * *$ & $0.000205^{* *}$ & -0.00559 & $0.0725 * *$ \\
\hline & $(0.000220)$ & $(0.000185)$ & $(0.0890)$ & $(0.0693)$ \\
\hline \multirow[t]{2}{*}{ dop } & $0.000613 * * *$ & $0.000366 * * *$ & $0.00146 * *$ & $0.00158 * *$ \\
\hline & $(0.000115)$ & $(8.89 \mathrm{e}-05)$ & $(0.000655)$ & $(0.000657)$ \\
\hline \multirow[t]{2}{*}{ fop } & $-0.000135 * * *$ & $-7.06 \mathrm{e}-05^{* *}$ & 0.000918 & 0.0366 \\
\hline & (4.41e-05) & $(3.49 \mathrm{e}-05)$ & $(0.0466)$ & $(0.0355)$ \\
\hline Observations & 415 & 429 & 56 & 70 \\
\hline Number of countries & 14 & 14 & 14 & 14 \\
\hline
\end{tabular}

Standard errors in parentheses

$* * * \mathrm{p}<0.01, * * \mathrm{p}<0.05, * \mathrm{p}<0.1$

Source: Author, 2015(from UNCTAD Stat and WDI)

First, the paried effect of FDI and domestic investment (fd,) is significant at 5\%,which reveals the mutual contribution of foreign and domestic investment to economic growth. Also it shows the domestic and foreign investment complement each other via technology exchange, providing domestic competitiveness, sharing market information ,etc. Second, the estimate of domestic investment and openness together (dop) has positive and significant effect on growth rate. This implies the presence of dynamic relationship between foreign trade and domestic investment. Export-led economic policy induces domestic investment on exportable items and increased investment, which may lead to more trade from increased export earnings, keeping all other factors constant ( Krugman \& Obstfeld, 2006; Sala \& Trivin, 2014). Third, the effect of FDI and trade openness (fop) on Y is negative and significant. This may be due to the fact that foreign firms were not adequately producing exportable goods for world market. As a result, strategic sector identification and provision of special policy support is advaisble for more trade gain.

\section{Conclusion}

The study has analyzed the impact of FDI on economic growth in 14 Eastern African countries by using dynamic GMM estimators after conducting appropriate tests.

All the three hypothesises were statistically tested to be valid. First, FDI has positive and marginally significant impact on economic growth in Eastern Africa. The effect is only mariginal due to weak absorptive capacity of the sub-region,which is related to poor human capital and infrastructure development. Most of the other growth 
determinants showed direct effect on growth, while regional dummies showed odd results. The economic conditional convergence was found at 5\%, which is higher than Sub-Saharan Africa (4\%), which is accrue to forlonged geographical, cultural, socio-economic networks. As per third hypotheis, FDI do not significantly crowd out domestic investment rather it complements. Furthermore, the mutual effect of domestic investment and trade openness on growth was positive and significant. This means that foreign trade and domestic investment are directly related.

In general, there is positive and marginally significant effect of FDI on growth, rate of economic conditional convergence is 5\%, absence of significant crowding out effect from FDI to domestic investment, interdependence of domestic investment and openness, and macroeconomic instability in the short-run. The findings confirm with some studies (Njoupouognigni \& Ndambendia, 2010; Sukar \& Hassan, 2011; Kabundi \& Loots, 2012; Zakari et.al.,2012; Lenka \& Sharma, 2015; Agrawal,2015; Sala \& Trivin,2015) and don't confirm with that of Alege \& Ogundipe ( 2013). Thus, FDI is a key deriver of economic growth and catalyst to economic conditional convergence in Eastern Africa.

Accordndly, to enhance investment and economic growth, Eastern Africa need to attract more FDI and retain them by impoving investment enviroment, building key infrastructure, invest more on human capital , increase regional integration, strengthen internal coordination and external relation, follow export-oriented investment, and careful impact evaluation is very important.

\section{References}

Abadi, B. M. (2011). The Impact of Foreign Direct Investment on Economic Growth in Jordan. IJRRAS, 8(2).

Abdalla, K. A. (2013). The Impact of Human Capital on Economic Growth: Empirical Evidence from Sudan. Research in World Economy, 4(2). http://dx.doi.org/10.5430/rwe.v4n2p43.

Abdul, K. (2007). Foreign Direct Investment and Economic Growth: Empirical Evidence from Sectoral Data in Indonesia. Indonesia, Andalas University.

Adb, A. D. (2013). Annual Development Effectiveness Review 2013: Towards Sustainable Growth for Africa (3rd ed.). Tunisia: African Development Bank.

African Development Bank [AfDB]. (2014). A Partner of Choice for the Eastern Africa we want. Nairobi, Kenya: African Development Bank Group - East Africa Regional Resource Centre (EARC).

Agrawal, G. (2015). Foreign Direct Investment and Economic Growth in BRICS Economies: A Panel Data Analysis. Journal of Economics, Business and Management, 3(4), April 2015. http://dx.doi.org/10.7763/JOEBM.2015.V3.221

Agrawal, G. (2011). Impact of FDI on GDP Growth: A Panel Data Study. European Journal of Scientific Research, 57(2), 257-264.

Altman, D. (2014). The Baseline Profitability Index (BPI). New York: New York University's Stern School of Business.

Alege P., \& Ogundipe, A. (2013). Sustaining Economic Development of West African Countries: A System GMM Panel Approach. MPRA Paper, 51702. Nigeria: Cvenant University, Ota, Ogun State.

Alfaro L., Chanda A., Kalemli-Ozcan S., \& Sayek S. (2003). FDI and Economic Growth: the Role of Local Financial Market. Journal of International Economics volume 64. JEL Classification: F23, F36, F43

Anderson, T. W. (1982). Formulation and Estimation of Dynamic Models Using Panel Data. Journal of Econometrics., $18,67-82$.

Ayanwale, A. B. (2007). FDI and Economic Growth: Evidences from Nigeria. Africa Economic Research Consortium, Nairobi, Research Paper, 165.

Akinlo, A. E. (2004). Foreign Direct Investment and Growth in Nigeria: An Empirical Investigation. Journal of Policy Modelling, 26(3), 627-39.

Analyse Africa. (2015). Africa Investment Report 2015, FDI Intelligence. (Reprinted from; http:llwww. analyzeafrica.com/?utm_Source=Africa-Investment-Report\& utm_medium.

Arellano, M., \& Bond, S. (1991). Some Tests of Specification for Panel Data: Monte Carlo Evidence and Application to Employment Equation. Review of Economic Studies, 58(2), 277-297.

Arellano, M., \& Bover, O. (1995). Another Look at the Instrumental Variable Estimation of Error-componentsModels. Journal of Econometrics, 68(1), 29-51.

Assefa, G. H. (2006). Determinants of Foreign Direct Investment in Ethiopia: A Timeseries Analysis. Retrieved from Westminster Research website:

Asiedu, E. (2004). Policy Reform Foreign Direct Investment in Africa:Absoulute Progress but Relative Decline, 22. Oxford OX4 2DQ ,UK and 350 Main street Malden ,MA 02148,USA: Balckwell Publishing. 
Balasubramanyam, M. S. (1996). Foreign Direct Investment and Growth in EP and is Countries. The Economic Journal,, 106(434), 92-105.

Barro, R. J. (1991). Economic Growth in a Cross Section of Countries. The Quarterly. Journal of Economics, 106(2), $407-43$.

Barro, R. J. (2000). Inequality and Growth in a Panel of Countries. Journal of Economic Growth, 5 (1): 5-32.

Beck, T., Levin, R., \& Loayza, N. (2000). Finance and the Sources of Growth. Journalnof Financial Economics, 58(12), 261-300.

Beugelsdijk, R. S., \& Zwinkels, R. (2008). The Impact of Horizontal and Vertical FDI on Host Country Economic Growth. International Business Review, 17, 452-472.

Bichaka, F. (2008). The Impact of Remittances on Economic Growth and Development in Africa. Department Of Economics and Finance Working Paper Series.

Blundell, \& Bond. (1998). Initial Conditions and Moment Restrictions in Dynamic Panel Data Models. Journal of Econometrics., 87, 15-143.

Borensztein, E., De Gregorio, J., \& Lee, J. W. (1998). How Does Foreign Direct Investment Affect Economic Growth? Journal of International Economics, 45, 115-135.

Brambor, T. (2006). Understanding Interaction Models: Improving Empirical Analyses. Political Analysis, 14, 63-82. http://dx.doi.org/ 0.1093/pan/mpi014.

Bosworth, P., \& Collins S. (1999). Capital Flows to Developing Economies: Implications for Saving and Investment. Brookings Papers on Economic Activity:1, Brookings Institution, 143-69.

Croson R., Gomes A., Mcginn K., \& Noth, M. (2004). Mergers and Acquisitions: An Experimental Analysis of Synergies, Externalities and Dynamics. Review of Finance, 8, 481-514. Netherlands, Kluwer Academic Publishers.

DeMello, L. R. (1997). Foreign Direct Investment in Developing Countries and Growth: A Selective Survey. The Journal of Development Studies, 34(1), 115-135.

Dunning, J. H. (2000). The Eclectic Paradigm as an Envelope for Economic and Business Theories of MNE Activity. International Business Review, 9(2000), 163-190.

Dunning, J. H. (1993). The Globalization of Business:The Challenge of the 1990s. London and New York: Routledge.

Eddine A. S., Fakhri I., \& Salem B. (2014). Financial Liberalization, Foreign Direct Investment (FDI) and Economic Growth: A Panel Dynamic Data Validation. Retrieved from http://mpra.ub.uni muenchen.de/56386/.

Esso, L. J. (2010). Long-Run Relationship and Causality between Foreign Direct Investment and Growth: Evidence from Ten African Countries. International Journal of Economics and Finance, 2(2), 10.

Gattai, V. (2006). From the Theory of the Firm to FDI and Internalization: A Survey. Giornale degli Economisti e Annali di Economia, Nuova Serie, 65(2), 225-261.

Gupta, P. (2006). An Investigation of Openness and Economic Growth Using Panel Estimation Department of Economics Working Paper Series.

Havlik, R. D. (2013). Economic Convergence and Structural Change: the Role of Transition and EU Accession. Vienna Institute for International Economic Studies.

Hymer, S. H. (1976). The International Operations of National Firms:PhD Thesis (PhD). USA:MIT Press

Ilhan, O. (2007). Foreign Direct Investment - Growth Nexus: A Review of the Recent Literature. International Journal of Applied Econometrics and Quantitative Studies, 42, 79-98.

IMF. (2009). Balance of Payments and International Investment Position Manual:Sixth Edition BPM6, Retrieved from www.imfbookstore.org .

Kabundi A., \& Loots, E. (2012). Foreign Direct Investment to Africa: Trends, Dynamics and Challenges. SAJEMS NS, $15(2)$.

Kaitila, V. (2005). Integration and Conditional Convergence in the Enlarged Eu Area. Enepri Working Paper, 31.

Kinyondo, M. (2012). Determinants-of-Foreign-Direct-Investment. Global Journal of Management and Business Research, 12(18), 20.

Kotrajaras, P. (2010). Foreign Direct Investment and Economic Growth: A Comparative Study among East Asian Countries. Applied Economics Journal, 17(2), 12-26. 
Krugman P., \& Obstfeld, M. (2006). International Economics: Theory and Policy (9th ed.). English:Pearson Addison Welsey.

Lall, S. (2000). FDI and Development: Policy and Research Issues in the Emerging Context. QEH Working Paper Series.

Lamine, K. M. (2010). Foreign Direct Investment Effect on Economic Growth: Evidence from Republic of Guinea in West Africa. International Journal of Financial Research, 1(1).

Lenka S. K., \& Sharma P. (2015). FDI as a Main Determinant of Economic Growth:A Panel Data Analysis. Annual Research Journal of Symbiosis Centre for Management Studies,1, Januray 2013-January 2014, 84-9. Pune, Symbiosis Centre for Management Studies.

Lucas, R. E. (1988). On the mechanics of Economic Development. Journal of Monetary Economics, 22, 3-42.

Lumbila, K. N. (2005). What Makes FDI Work: A Panel Analysis of the Growth Effect of FDI in Africa. Africa Region Working Paper Series, 28.

Majeed, M. T. (2006). Determinants of Exports in Developing Countries. Pakistan Institute of Development Economics, Islamabad, 45(4), 1265-1276.

Mankiw, N. G., \& David, W. (1992). A Contribution to the Empirics of Economic Growth, Quarterly Journal of Economics, 107(2), 407-437.

Mann , M. K., Peterson L., \& Cosbey, A. ( 2005). International Institute for Sustainable Development [IISD] Model International Agreement on Investment for Sustainable Development:Negotiators' Handbook (sec. ed.). Canada, IISD.

Moreira, A. C. (2009). The Evolution of Internationalisation:Towards a New Theory? Portugal: Universidade de Aveiro.

Nelson, R., Edmund, S. (1966). Investment in Humans, Technological Diffusion, and Economic Growth. American Economic Association Papers and Proceedings, 56(1-2), 69-75.

Njoupouognigni M., \& Ndambendia H. (2010). Foreign Aid, Foreign Direct Investment and Economic Growth in Sub-Saharan Africa: Evidence from Pooled Mean Group Estimator (PMG). International Journal of Economics and Finance, 2(3).

Obwona, M. B. (2001). Determinants of FDI and Their Impact on Economic Growth in Uganda. African Development Review, 200, 46-80. UK: Blackwell Publishers Oxford.

OECD. (2008). OECD BenchmarkDefinition of Foreign Direct Investment. Paris: OECD.

OECD. (2002). Foreign Direct Investment for Development: Maximising Benefits,Minimising Costs, Overview. Paris: OECD.

Ozturk, I. (2007). Foreign Direct Investment - Growth Nexus: A Review of the Recent Literature. International Journal of Applied Econometrics and Quantitative Studies, 4(2), 79-98.

Patterson, N. , Motala J., \& Cardillo, C. (2004). Foreign Direct Investment: Trends, Data Availability, Concepts, and Recording Practices. Washington, D.C. IMF.

Peretto, P. F. (1998). Technological change and population growth. Journal of Economic Growth, 3, 283-311.

Rajan, R. S. (2004). Measures to Attract FDI: Investment Promotion, Incentives and Policy Intervention. Economic and Political Weekly, 39(1).

Romer, P. M. (1994). The Origins of Endogenous Growth. The Journal of Economic Perspectives, 8(1), 3-22.

Romer, P. M. (1990). Endogenous Technological Change. Journal of Political Economy, 98, S71-S102.

Romer, P. M. (1986). Increasing Returns and Long-run Growth. Journal of Political Economy, 94, 1002-1037.

Roodman, D. (2009). How to Do xtabond2: An Introduction to Difference and System GMM in Stata. The Stata Journal, 9(1), 86-136.

Rugman, A. M. (2010). "Reconciling Internationalization Theory and Eclectic Paradigm". Multinational Business Review, 18(2), PP 1-12. ISSN 1525-383X Available at http:// Centaur.reading.ac.uk/6112/.

Sala H., \& Trivin P. (2014). Openness, Investment and Growth in Sub-Saharan Africa. Journal of African Economies, 1-33. http://dx. http://dx.doi.org/ 10.1093/jae/ejt027.

Sandretto, M. S. (2008). Foreign Direct Investment, Macroeconomic Instability and Economic Growth in MENA Countries. Economic Commission for Africa, 69. 
Soci, A. (2002). FDI: The Current State of Play: Anna Soci,Department of Economics, University of Bologna.

Solomon, W. D. (2008). Determinants of Foreign Direct Investment in Ethiopia. Maastricht, The Netherlands : Maastricht University.

Spatz, P. N. (2004). FDI and EGrowth in Developing Economies: How Relevant are Host-economy and Industry characteristics, In UNCTAD (Ed.), Transnational Corporations, 13. New York and Geneva: United Nations.

Sukar, A., \& Hassan, S. (2011). The Effects of Foreign Direct Investment on Economic Growth: The Case of Sub-Sahara Africa. Southwestern Economic Review.

Sukar A., \& Hassan, S. (2007). The Effects of Foreign Direct Investment on Economic Growth: The Case of Sub-Sahara Africa. Southwestern Economic Review.

Sukar A., Ahmed, S., \& Hassan, S. (2004).The Effects of Foreign Direct Investment on Economic Growth:The Case of Sub-Sahara Africa. Southwestern Economic Review.

Todaro, M. P., \& Smith, S. C. (2012). Economic Development, (11 ${ }^{\text {th }}$ ed.). New York San Francisco Upper Saddle River: Addison-Wesley.

UNCTAD. (2014). World Investment Report, Overview , Investing in the SDGs: An Action Plan. Geneva Switzerland: UNCTAD.

UNCTAD. (2014). Global Investment Monior, UNCTAD.

UNCTAD. (2013a). Global Value Chains: Investment and Trade for Development. World Investment Report. New York: United Nations.

UNCTAD. (2013b). The State of Industrial Development in Africa: Unexploited Opportunities Amidst Growing Challenges. Policy Brief, 27. New York and Geneva: UNCTAD.

UNCTAD. (2012).Economic Development in Africa: Structural Transformation and Sustainable Development in Africa Report 2012, 160. Geneva Switzerland: UNCTAD.

UNCTAD. (2008). Export competitiveness and Development in LDCs: Policies,Issues and Priorities for Least Developed Countries for Action During \& Beyond UNCTAD XII. New York \& Geneva: United Nations.

UNCTAD. (1999). World Investment Report 1999:Foreign Direct Investment and the Challenge of Development. New York and Geneva: United Nations.

WIR. (2007). World Investment Report 2012: Methodological Note World Investment Report 2012: Towards a New Generation of Investment Policies, World Inestment Report.

Wooldridge, J. M. (2001). Applications of Generalized Method of Moments Estimation. Journal of Economic Perspectives, 15(4), 87-100.

Wooldrigge, J. M. (2005). Introductory Econometrics:A Modern Aproach.

World Economic Forum[WEF].(2015). The Africa Competitiveness Report 2015. Geneva; World Economic Forum, ISBN-13: 978-92-95044-00-5.

Young, A., Higgins, J., \& Levy, D. (2008). Sigma Convergence Versus Beta Convergence: Evidence from U.S. County-level Data'. Journal of Money, Credit and Banking, 40(5), 1083-1093.

Zakari A., Mohammed, H., \& Adamu, Y. (2012). Does FDI Cause Economic Growth? Evidence from Selected Countries in Africa and Asia. African Journal of Social Sciences, 2(4).

\section{(cc) $\mathrm{BY}$}

This work is licensed under a Creative Commons Attribution 3.0 License. 